\title{
THE EFFECT OF PREPARTUM ANTIOXIDANT ADMINISTRATIONS ON BLOOD BHBA CONCENTRATION IN COWS
}

\author{
INEKLERDE PREPARTUM ANTIOKSIDAN UYGULAMALARININ KAN BHBA \\ KONSANTRASYONU ÜZERINE ETKISI
}

\author{
Serdal KURT ${ }^{1, * *}$, Mert PEKCAN ${ }^{2}$, Rıfat VURAL ${ }^{1}$, Şükrü KÜPLÜLÜ ${ }^{1}$,* \\ ${ }^{1}$ Ankara University, Faculty of Veterinary Medicine, Department of Obstetrics and \\ Gynecology, 06110, Ankara Turkey \\ ${ }^{2}$ Ankara University, Faculty of Veterinary Medicine, Department of Biochemistry, 06110, \\ Ankara, Turkey
}

\begin{abstract}
Objective: The aim of this study was to investigate the effect of prepartum antioxidant administrations on blood Beta-hydroxybutyric acid (BHBA) concentration on day 7 postpartum in Holstein dairy cows.

Antioxidants are defined as substances that delay or inhibit oxidative damage. Oxidants, such as reactive oxygen species (ROS) are produced as a consequence of adenosine triphosphate (ATP) production in mitochondria. Oxidants can cause tissue damage by damaging cells' macromolecules, such as deoxyribonucleic acid, proteins, and lipids. Lipids are the most sensitive macromolecules against oxidative damage. Oxidative stress can both disrupt the mechanism of insulin and induce more lipolysis. Therefore, ROS overproduction can enhance non-esterified fatty acids (NEFA) and BHBA production.

Material and Method: Eighty pregnant multiparous Holstein dairy cows were used in this study. The cows were divided into treatment $(G 1 ; n=40)$ and control groups $(G 2 ; n=40)$. Solutions containing vitamins $(A, D, E)$ and trace elements $(\mathrm{Cu}, \mathrm{Se}, \mathrm{Mn}, \mathrm{Zn})$ were administered intramuscularly to $\mathrm{Gl}$ on $21 \pm 5$ and $10 \pm 5$ days before the expected delivery time (280 days). G2 was given the same amount of saline injections as the placebo.

Result and Discussion: It was found that blood BHBA concentrations were lower in the G1 (0.73 \pm 0.20 $\mathrm{mmol} / \mathrm{L})$ compared to the $G 2(0.84 \pm 0.29 \mathrm{mmol} / \mathrm{L})$. In conclusion, it was determined that prepartum antioxidant administrations decrease blood BHBA concentration in the postpartum period in dairy cows.
\end{abstract}

Keywords: antioxidant; $B H B A$; cow; oxidative stress

\footnotetext{
* Corresponding Author / Sorumlu Yazar: Şükrü Küplülü

e-mail: skuplulu@ankara.edu.tr

** This article was produced from the Ph.D. thesis/Bu makale doktora tezinden üretilmiştir

Submitted/Gönderilme: 11.03.2019 Accepted/Kabul: 19.04.2019
} 


\section{ÖZ}

Amaç: Sunulan çalışmada, Holstein sütçü ineklerde prepartum antioksidan uygulamalarının postpartum 7. günde kan Beta-hidroksibütirik asid (BHBA) konsantrasyonu üzerine etkisinin araştırllması amaçlandl. Antioksidanlar oksidatif hasarl geciktiren veya engelleyen maddeler olarak tanımlanmaktadır. Reaktif oksijen türleri (ROS) gibi oksidan maddeler mitokondrilerde adenozin trifosfat (ATP) üretiminin bir sonucu olarak oluşturulur. Oksidan maddeler hücrelerin dezoksiribonükleik asit, proteinler ve lipidler gibi makromoleküllerine zarar vererek doku hasarına neden olabilir. Lipitler oksidatif hasara karşl en hassas makromoleküllerdir. Oksidatif stres insülin mekanizmasını bozarak daha fazla lipolize neden olabilir. Böylece, aşırı derecede ROS üretimi esterleşmemiş yă asitlerini (NEFA) ve BHBA üretimini artırabilir.

Gereç ve Yöntem: Bu çalışmada 80 adet multipar Holstein ırkl gebe sütçü inek kullanıldı. Inekler, tedavi $(G 1 ; n=40)$ ve kontrol grubu $(G 2 ; n=40)$ olmak üzere iki gruba ayrlld. $G 1$ 'e vitamin $(A, D, E)$ ve iz element $(\mathrm{Cu}, \mathrm{Se}, \mathrm{Mn}, \mathrm{Zn})$ içeren solüsyonlar beklenen doğum tarihinden (280 gün) önce $21 \pm 5$ ve $10 \pm 5$ günlerde intramuskuler yolla uyguland. G2'ye, plasebo ile aynı miktarda serum fizyolojik enjeksiyonu yapıldi.

Sonuç ve Tartışma: Kan BHBA konsantrasyonlart G2'ye (0.84 $0.29 \mathrm{mmol} / \mathrm{L})$ göre G1'de $(0.73 \pm 0.20$ mmol/L) daha düşük bulundu. Sonuç olarak, sütçü ineklerde prepartum antioksidan uygulamalarının, postpartum dönemde kan BHBA konsantrasyonunu azalttı̆̆ tespit edildi.

Anahtar Kelimeler: antioksidan; BHBA; inek; oksidatif stres

\section{INTRODUCTION}

Antioxidants are defined as substances that delay or inhibit oxidative damage [1,2]. These substances, are obtained in two different ways as endogenous (enzymatic (such as superoxide dismutase (SOD), glutathione peroxidase (GPX) and catalase), and non-enzymatic (such as glutathione, uric acid, melatonin, bilirubin, albumin)) and exogenous (such as Vitamins of A, E, D and C, selenium (Se), copper $(\mathrm{Cu})$, manganese $(\mathrm{Mn})$, zinc $(\mathrm{Zn}))[3,4]$. Enzymatic and non-enzymatic antioxidants work in concert [5] and protect the body against oxidative damage [5, 6]. Moreover, exogenous antioxidants are used in the structure of endogenous antioxidants [4]. For example, SOD enzymes depend on $\mathrm{Cu}$ and $\mathrm{Mn}$ to provide the dismutation of $\mathrm{O}_{2}^{-}$to $\mathrm{H}_{2} \mathrm{O}_{2}$. Later on, the reduction of $\mathrm{H}_{2} \mathrm{O}_{2}$ to $\mathrm{H}_{2} \mathrm{O}$ and $\mathrm{O}_{2}$ is ensured by catalases or Se-dependent GPx and thioredoxin reductase (Trx) enzymes [4]. However, when the production of oxidant substances exceeds the body's antioxidant capacity, oxidative stress occurs [7]. Free radicals are produced during the conversion of foods into a form of ATP using $\mathrm{O}_{2}$ in mitochondria $[8,9]$. And, reactive oxygen species (ROS) such as $\mathrm{H}_{2} \mathrm{O}_{2}, \mathrm{HO}_{-}, \mathrm{HO}_{2}, \mathrm{O}_{2}{ }^{-}, \mathrm{ROO}{ }^{\circ}$ [9] are the most abundant free radicals in biological systems. ROS can cause tissue damage by damaging cells' macromolecules, such as deoxyribonucleic acid, proteins, and lipids [2]. It was reported that lipids are the most sensitive macromolecules against to oxidative damage [10]. Oxidative stress can induce more lipolysis [2] and disrupt the mechanism of insulin in cows [11]. Therefore, ROS overproduction enhances non-esterified fatty acids (NEFA) and beta-hydroxybutyric acid (BHBA) production and results in metabolic stress in dairy cows [2]. Furthermore, because it is difficult to maintain an energy balance due to increased metabolic activities and nutritional needs in the periparturient period, dairy cows already experience a negative energy balance (NEB) [12]. NEB also induces the mobilization of body fat in the form of NEFA and subsequently it results in the increase in blood BHBA concentrations [13]. High levels of BHBA impair hepatic function and adversely affect health in many ways [14]. Antioxidants improve the 
mechanism of glucose and insulin in dairy cows [11]. But, the production of oxidants and the use of antioxidants are significantly increased due to increased metabolic activity during this period. For these reasons, the need for antioxidants increases and antioxidant therapy can be necessary in periparturient cows $[5,15]$

The aim of this study was to investigate the effect of prepartum vitamins (A, D, E) and trace element $(\mathrm{Cu}, \mathrm{Zn}, \mathrm{Se}, \mathrm{Mn})$ administration on blood BHBA concentrations on day 7 postpartum in Holstein dairy cows.

\section{MATERIAL AND METHOD}

Animals

Eighty pregnant multiparous Holstein dairy cows from a commercial dairy herd in Aksaray, Turkey were used in this study. The cows had a milk yield of about 10,000 kg (per cow, per lactation), were milked twice daily, received periodic systematic vaccination, were fed with a total mix ration (TMR), were managed in free-stall barns and were clinically healthy. And the cows had a similar body condition score. The cows were divided into treatment $(\mathrm{G} 1 ; \mathrm{n}=40)$ and control group $(\mathrm{G} 2 ; \mathrm{n}=40)$ by the randomized grouping method.

Experimental Design

Eight $\mathrm{ml}$ of solutions (Ademin ${ }^{\circledR}$, Ceva) containing vitamins A, D and E (500,000 I.U. of vitamin A, 75,000 I.U. of vitamin $\mathrm{D}_{3}$, and $50 \mathrm{mg}$ of vitamin $\mathrm{E}$ per $\mathrm{ml}$ ) and $10 \mathrm{ml}$ of solutions (Activate ${ }^{\circledR}$, Alke) containing $\mathrm{Cu}, \mathrm{Se}, \mathrm{Mn}$ and $\mathrm{Zn}$ trace elements ( $2.5 \mathrm{mg}$ of copper gluconate, $1.25 \mathrm{mg}$ of sodium selenite, $5 \mathrm{mg}$ of manganese gluconate, and $5 \mathrm{mg}$ of zinc gluconate per $\mathrm{ml}$ ) were administered intramuscularly using a 18 -G cannula to each cow into G1 on $21 \pm 5$ and $10 \pm 5$ days before expected delivery time (280 days). G2 was given in the same amounts of saline injections as a placebo to each cow.

Analysis

Blood samples were collected from the coccygeal vein into vacutainer tubes using $18-\mathrm{G}$ needles. Before clotting, blood BHBA concentrations were measured using a hand-held meter Vet TD-4235 $\beta$ ketone monitoring system (Hasvet, Turkey) and commercial kits (LOT: WK18D923-B0E, Hasvet, Turkey) within 1 minute after sampling on day $7 \pm 3$ postpartum.

Statistical analysis

Individual cow data were exported from farms' herd management software (Dairy Plan, GEA Farm Technologies, ABD) to Microsoft Excel. Statistical analysis was performed with SPSS software (Version 14.01). The conformity of the data to the normal distribution was evaluated with the shapirowilk test. And the distribution was found as normal. For this reason, the relationship between blood BHBA concentrations and groups (G1 and G2) was performed with an Independent Sample t-Test. The statistical analysis limit was accepted as $\mathrm{p}<0.05$. 


\section{RESULT AND DISCUSSION}

In the results of this study, it was found that blood BHBA concentrations were lower in the G1 $(0.73 \pm 0.20 \mathrm{mmol} / \mathrm{L})$ compared to the $\mathrm{G} 2(0.84 \pm 0.29 \mathrm{mmol} / \mathrm{L})$. In addition, BHBA results were significant because of the $\mathrm{p}$-value $<0.05$ (Table 1 ).

Table 1. Comparison of the blood BHBA concentrations in G1 and G2.

\begin{tabular}{cccc}
\hline & G1 & G2 & $p$ \\
\hline BHBA $(\mathrm{mmol} / \mathrm{L})$ & $0.73 \pm 0.20$ & $0.84 \pm 0.29$ & 0.046 \\
\hline
\end{tabular}

It was also detected that G1 and G2 had different BHBA distributions. And blood BHBA concentrations were lower in G1 compared to G2. But, the lowest BHBA values were measured to be $0.2 \mathrm{mmol} / \mathrm{l}$ and $0.4 \mathrm{mmol} / \mathrm{l}$ in G2 and in G1, respectively (Figure 1). At the end of this study, it was thought that the lipolysis rate was lower in G1 than G2.

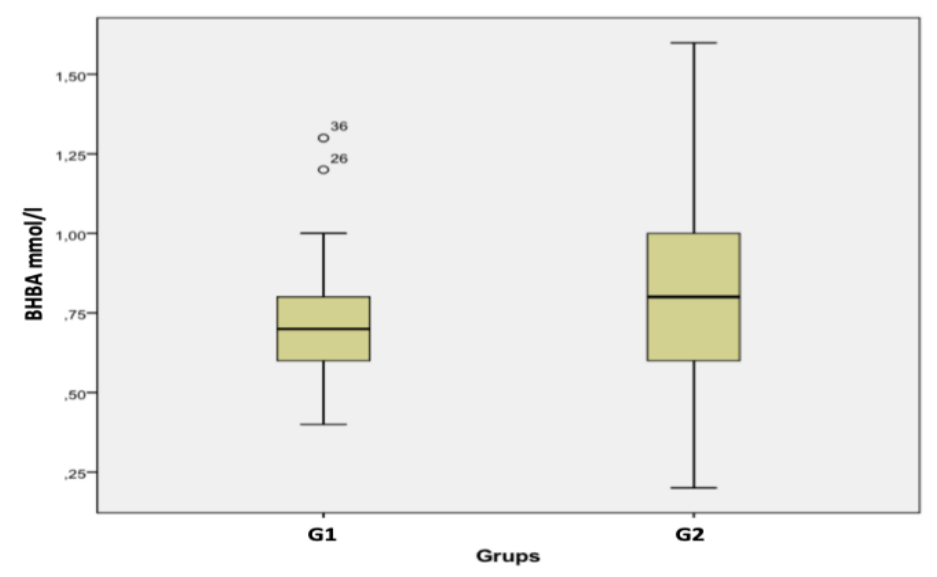

Figure 1. Blood BHBA distributions in $\mathrm{G} 1$ and $\mathrm{G} 2$ on day 7 postpartum in Holstein dairy cows.

Moderate levels of ROS are required for physiological processes like cell differentiation or proliferation and host immune response [2]. The overproduction of free radicals has an important roll in the development of ailments such as cancer, aging, autoimmune disorders, cardiovascular and neurodegenerative diseases [9]. For these reasons, antioxidants are indispensable substances for the body [3]. Antioxidant administrations before calving can have a positive effect on the mechanism of glucose and insulin in dairy cows [11]. Furthermore, insulin has an antilipolytic effect on fat tissue [16]. Oxidative stress can cause insulin resistance [11], and when the antilipolytic effect of insulin deteriorates, lipolysis is stimulated [16]. 
It was reported that lipids are the most sensitive macromolecules against oxidative damage of ROS in the body [10]. Another study showed that lipolysis increased ROS production [17]. Some researchers declared that overproduction of ROS increases NEFA and BHBA concentrations in the blood of dairy cows [2]. Moreover, inadequate levels of essential vitamins and trace elements result in diminished functional capabilities of immune cells. If ROS cannot be neutralized, its rate increases in the body [5]. Thus, the BHBA concentration increases due to lipolysis and then diseases enhance. These cases are more complex in the periparturient period because cows are already in NEB and oxidative stress. Therefore, the supplementation of antioxidants is very important during this period [2].

In another study, vitamin $\mathrm{E}$ and Se were administered to Holstein cows intramuscularly at $15 \pm 2$ days before expected calving. It was found that blood BHBA levels were lower in the treatment group $(10.31 \mathrm{mg} / \mathrm{dL})$ compared to the control group $(13.81 \mathrm{mg} / \mathrm{dL})$ on days 3-7 postpartum (p-value nonsignificant). Moreover, an intravenous glucose tolerance test was performed on these cows on days 3-7 postpartum and better results were obtained in the treatment group compared to the control group [11].

It was reported that the blood BHBA normal level was less than $0.6 \mathrm{mmol} / \mathrm{l}$ in dairy cows [18]. In another study, it was suggested that the threshold value of BHBA was $1.200 \mu \mathrm{mol} / \mathrm{L}$ [19]. But, blood BHBA levels increase due to increased metabolic demands and NEB in the periparturient period [2]. In our study, the level of BHBA was found to be $0.73 \pm 0.20 \mathrm{mmol} / \mathrm{l}$ and $0.84 \pm 0.29 \mathrm{mmol} / \mathrm{l}$ on the 7 th day postpartum in G1 and G2, respectively.

In conclusion, it was determined that prepartum antioxidant administrations decrease blood BHBA concentration in the postpartum period in dairy cows. Moreover, low levels of BHBA concentration in G1 showed the efficacy of antioxidants on lipolysis when compared to G2. Furthermore, it is thought that antioxidant administrations caused this effect by reducing the harmful effects of free radicals and improving the mechanism of insulin and glucose.

\section{ACKNOWLEDGEMENT}

This article was produced from the Ph.D. thesis titled 'Investigation Effect of Prepartum Antioxidant Administration on Oxidative Stress Energy Metabolism and Colostrum Quality in Cows' which belongs to Serdal Kurt. Ankara University-Scientific Research Projects (BAP) Coordinator project number: 18L0239022.

\section{REFERENCES}

1. Sen, S., Chakraborty, R., Sridhar, C., Reddy, Y. S. R., De, B. (2010). Free radicals, antioxidants, diseases and phytomedicines: current status and future prospect. International Journal of Pharmaceutical Sciences Review and Research, 3(1), 91-100. 
2. Abuelo, A., Hernández, J., Benedito, J. L., Castillo, C. (2015). The importance of the oxidative status of dairy cattle in the periparturient period: revisiting antioxidant supplementation. Journal of animal physiology and animal nutrition, 99(6), 1003-1016.

3. Sen, S., Chakraborty, R. (2011). The role of antioxidants in human health. Oxidative stress: diagnostics, prevention, and therapy, 1083, 1-37.

4. Mavangira, V., Sordillo, L. M. (2018). Role of lipid mediators in the regulation of oxidative stress and inflammatory responses in dairy cattle. Research in veterinary science, 116, 4-14.

5. Sordillo, L. M., Aitken, S. L. (2009). Impact of oxidative stress on the health and immune function of dairy cattle. Veterinary immunology and immunopathology, 128(1-3), 104-109.

6. Köroğlu, A., Hürkul, M. M., Kendir, G., Küçükboyacı, N. (2019). In vitro antioxidant capacities and phenolic contents of four Erica L.(Ericaceae) taxa native to Turkey. Marmara Pharmaceutical Journal, 23(1), 93-100.

7. Batistel, F., Arroyo, J. M., Garces, C. I. M., Trevisi, E., Parys, C., Ballou, M. A., Loor, J. J. (2018). Ethyl-cellulose rumen-protected methionine alleviates inflammation and oxidative stress and improves neutrophil function during the periparturient period and early lactation in Holstein dairy cows. Journal of dairy science, 101(1), 480-490.

8. Puppel, K., Kapusta, A., Kuczyńska, B. (2015). The etiology of oxidative stress in the various species of animals, a review. Journal of the Science of Food and Agriculture, 95(11), 21792184.

9. Pham-Huy, L. A., He, H., Pham-Huy, C. (2008). Free radicals, antioxidants in disease and health. International journal of biomedical science: IJBS, 4(2), 89.

10. Kuhn, M. J., Mavangira, V., Gandy, J. C., Sordillo, L. M. (2018). Production of 15-F2tisoprostane as an assessment of oxidative stress in dairy cows at different stages of lactation. Journal of dairy science, 101(10), 9287-9295.

11. Abuelo, A., Alves-Nores, V., Hernandez, J., Muiño, R., Benedito, J. L., Castillo, C. (2016). Effect of parenteral antioxidant supplementation during the dry period on postpartum glucose tolerance in dairy cows. Journal of veterinary internal medicine, 30(3), 892-898.

12. Zebeli, Q., Ghareeb, K., Humer, E., Metzler-Zebeli, B. U., Besenfelder, U. (2015). Nutrition, rumen health and inflammation in the transition period and their role on overall health and fertility in dairy cows. Research in veterinary science, 103, 126-136.

13. Wankhade, P. R., Manimaran, A., Kumaresan, A., Jeyakumar, S., Ramesha, K. P., Sejian, V., Varghese, M. R. (2017). Metabolic and immunological changes in transition dairy cows: A review. Veterinary world, 10(11), 1367. 
14. Esposito, G., Irons, P. C., Webb, E. C., Chapwanya, A. (2014). Interactions between negative energy balance, metabolic diseases, uterine health and immune response in transition dairy cows. Animal reproduction science, 144(3-4), 60-71.

15. Lykkesfeldt, J., Svendsen, O. (2007). Oxidants and antioxidants in disease: oxidative stress in farm animals. The Veterinary Journal, 173(3), 502-511.

16. Chang, Y. C., Chuang, L. M. (2010). The role of oxidative stress in the pathogenesis of type 2 diabetes: from molecular mechanism to clinical implication. American journal of translational research, 2(3), 316.

17. Song, Y., Li, X., Li, Y., Li, N., Shi, X., Ding, H., Wang, Z. (2014). Non-esterified fatty acids activate the ROS-p38-p53/Nrf2 signaling pathway to induce bovine hepatocyte apoptosis in vitro. Apoptosis, 19(6), 984-997.

18. Li, Y., Ding, H. Y., Wang, X. C., Feng, S. B., Li, X. B., Wang, Z., Li, X. W. (2016). An association between the level of oxidative stress and the concentrations of NEFA and BHBA in the plasma of ketotic dairy cows. Journal of animal physiology and animal nutrition, 100(5), 844-851.

19. Zarrin, M., De Matteis, L., Vernay, M. C. M. B., Wellnitz, O., van Dorland, H. A., Bruckmaier, R. M. (2013). Long-term elevation of $\beta$-hydroxybutyrate in dairy cows through infusion: Effects on feed intake, milk production, and metabolism. Journal of dairy science, 96(5), 2960-2972. 